DIW BERLIN

Discussion Papers

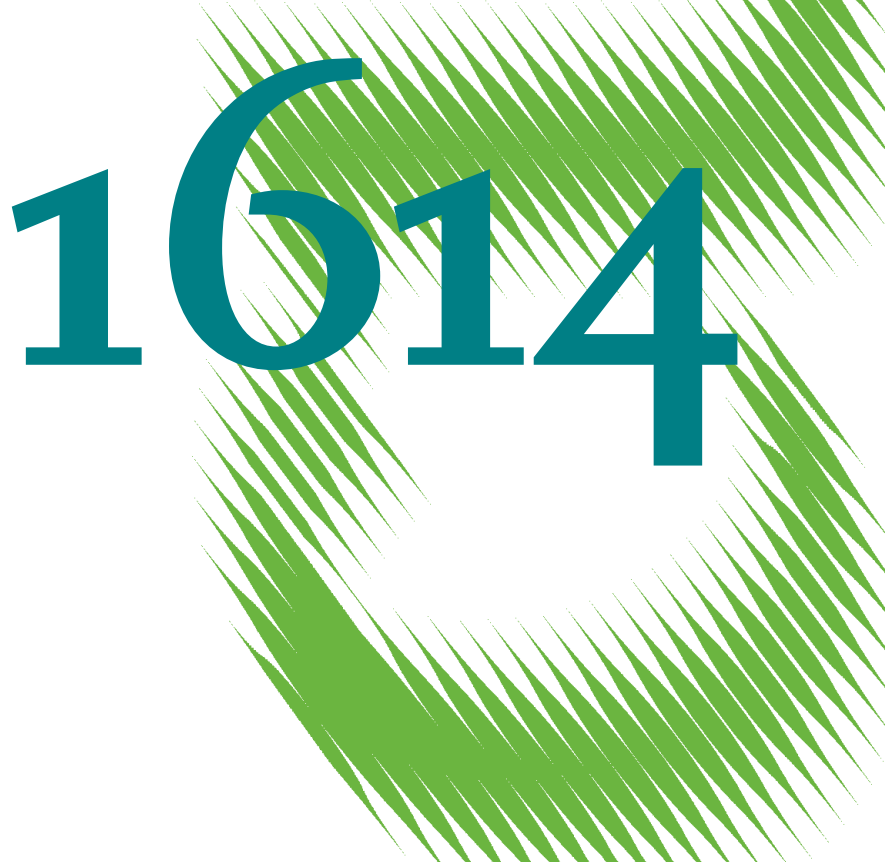

Market Power and Heterogeneous Pass-Through in German Electricity Retail 
Opinions expressed in this paper are those of the author(s) and do not necessarily reflect views of the institute.

IMPRESSUM

(C) DIW Berlin, 2016

DIW Berlin

German Institute for Economic Research

Mohrenstr. 58

10117 Berlin

Tel. +49 (30) $89789-0$

Fax +49 (30) $89789-200$

http://www.diw.de

ISSN electronic edition 1619-4535

Papers can be downloaded free of charge from the DIW Berlin website:

http://www.diw.de/discussionpapers

Discussion Papers of DIW Berlin are indexed in RePEc and SSRN:

http://ideas.repec.org/s/diw/diwwpp.html

http://www.ssrn.com/link/DIW-Berlin-German-Inst-Econ-Res.html 


\title{
Market Power and Heterogeneous Pass-through in German Electricity Retail *
}

\author{
Tomaso Duso ${ }^{\dagger}$ and Florian Szücs
}

October 26, 2016

\begin{abstract}
We analyze the pass-through of cost changes to retail tariffs in the German electricity market over the 2007 to 2014 period. We find an average pass-through rate of around $60 \%$, which significantly varies with demand factors: while the pass-through rate to baseline tariffs, where firms have higher market power, is only $50 \%$, it increases to $70 \%$ in the competitive segment of the market. Although the pass-through rate of independent firms is significantly higher than that of other firms in the competitive market segment, the extent of supply-side heterogeneity is limited. Thus, the firms' ability to exercise market power appears to be constrained by competition and largely determined by demand side factors. Finally, we find that the pass-through rate in the competitive market segment has been approaching unity over the past years, indicating a rise in competitive pressure.
\end{abstract}

Keywords: Electricity retail, pass-through, Germany

JEL Codes: C23, D22, D43, L13, L94, Q41

\footnotetext{
*This paper is based on a study conducted on behalf of the Directorate General Competition of the European Commission. We thank Elena Argentesi, Albert Banal-Estañol, Anette Boom, Walter Beckert, Adriaan Dierx, Germain Gaudin, Klaus Gugler, Sven Heim, John Kwoka, Fabienne Ilkovitz, Mario Liebensteiner, Peter Ormosi, Julia Rechlitz, Luis-Manuel Schultz, Jo Seldeslachts, Jens Südekum, Catherine Waddams, Gregory J. Werden, and seminar participants at CBS, DICE Düsseldorf, WU Vienna, and DIW Berlin for their valuable comments. Ivan Mitkov provided excellent assistance during the data collection. Tomaso Duso gratefully acknowledges support from the Berlin Centre for Consumer Policies (BCCP).

$\dagger$ Deutsches Institut für Wirtschaftsforschung (DIW Berlin), DICE Düsseldorf, and Berlin Centre for Consumer Policies (BCCP), Mohrenstr. 58, 10117 Berlin, Germany. E-mail: tduso@diw.de.

$\ddagger$ Corresponding author. WU (Vienna University of Economics and Business), Welthandelsplatz 1, 1020 Vienna, Austria. E-mail: florian.szuecs@wu.ac.at.
} 


\section{Introduction}

Oil and gas prices have been fluctuating over the past two decades, but started declining in the 2010s. At the beginning of 2016 they reached their lowest value since 2003. Wholesale energy prices followed a similar pattern in most European economies as well as the US and, after a surge in the mid-2000s they are now at the level of the late 1990s. Yet, electricity retail prices did not seem to respond to these cost changes. Notwithstanding a decade of liberalization and deregulation as well as steadily increasing competitive pressure, European retail tariffs have rapidly increased since 2000. In a 2014 report, the European Commission finds that energy retail prices have increased by $4 \%$ annually across all member states over the 2008-2012 period, ${ }^{1}$ and the average increase in electricity retail prices between 2008 and 2013 amounts to $28 \%{ }^{2}$ Over the same time period, German retail prices increased on average by $36 \%$, while network charges increased by only $17 \%$ and wholesale energy prices dropped by $27 \% .^{3}$

Understanding the extent to which cost changes are transmitted to retail tariffs for final consumers - the pass-through - is imperative for policy makers; particularly in energy markets, which are in the spotlight of public opinion. Commentators regularly report that the cost savings in wholesale markets are not passed on to consumers and that the pass-through rate is very low. ${ }^{4}$ While several potential explanations are put forward in the theoretical literature on the sources of (a lack of) pass-through, empirical evidence to answer these questions, especially in the context of electricity markets, remains scarce.

This paper provides an empirical analysis of cost pass-through in the German retail market for electricity. Based on a detailed dataset of monthly electricity tariffs for different consumption bundles at the postal code level over the 2007 to 2014 period, we study how changes in the main cost drivers - such as network charges, concession fees and wholesale electricity prices - are transmitted to retail tariffs. We find that the average pass-through is incomplete at around $60 \%$. However, there are some dimensions of heterogeneity. The pass-through rate is lower in market segments where customers have higher switching costs. Baseline tariffs - the tariffs that households automatically get if they are not willing or able to switch retailer - respond less to cost shocks than the least expensive tariffs available, the more competitive segment of the market. However, even in the competitive segment of the market, pass-through is not complete. This might be due to long term supply contracts and some degree of market power by regional retailers.

\footnotetext{
${ }^{1}$ Energy prices and costs report, SWD(2014) 20 final/2.

${ }^{2}$ http://ec.europa.eu/eurostat/statistics-explained/index.php/Electricity_price_statistics

${ }^{3}$ Calculated from Verivox, ene't and EEX data, see section 4.

${ }^{4}$ See, for example, The Economist, 'Switched Off', February 13, 2016.
} 
We also find that the pass-through rate does not strongly depend on the identity of the retailer. We distinguish large, vertically integrated firms, municipal utilities, firms with a mixed ownership structure, and small independent retailers. The independent firms, which we assume to be most competitive, exhibit 15-20\% higher pass-through rates to the competitive market segment; the pass-through rates to baseline tariffs do not significantly differ across firms. This indicates that the ability to exercise market power is predominantly determined by demand side factors (consumer search and switching behavior) rather than by supply side factors (scale and vertical integration of retailers).

Moreover, we find a significant degree of time variation in pass-through rates. While pass-through to baseline tariffs remains relatively stable over time, pass-through to the most competitive tariffs is relatively low at the beginning of the sample period and increases to almost unity in the 2012 - 2014 period. It therefore seems that competitive pressure has increased in recent years in the more competitive market segment.

We focus on the retail electricity market in Germany for several reasons. First, retail energy markets, such as electricity and gas, have been in the spotlight in all major developed countries during the last decades, especially in Europe. Yet, in contrast to sectors like telecommunications, the liberalization, privatization, restructuring and deregulation of energy markets spurred by the EU Commission directive do not appear to have been fully successful. ${ }^{5}$ While almost all European countries have reached the stated objective of fully liberalized retail markets and entry has occurred on a large scale, direct benefits to consumers in terms of lower prices and better services do not seem to have fully materialized (e.g., Waddams Price (2005), Joskow et al. (2008), Su (2015)).

A second reason to focus on the German retail electricity market is data availability and reach. We were able to match several sources and create a very rich data-set with precise and high frequency (monthly data for eight years) postal code level information on retail tariffs as well as network charges. Moreover, we have data on wholesale electricity prices from the centralized market for electricity EEX - the leading European energy exchange located in Germany. These kinds of data are not easily available for other countries. A further advantage of focusing on electricity retail markets is that network charges and wholesale electricity prices account for more than $2 / 3$ of the cost of electricity, while the remaining third comprises mostly taxes and fees, which can easily be captured by fixed effects in the regressions. Moreover, most of these cost drivers can be considered to be exogenous to the retailers' pricing decisions. Therefore, we believe to be able to provide reasonable estimates of pass-through rates because we capture a substantial fraction of overall variable costs.

\footnotetext{
${ }^{5}$ See Directive 96/92/EC.
} 
Finally, electricity markets exhibit a large degree of heterogeneity in market structure both on the supply and on the demand side, which we can exploit econometrically. On the supply side, we observe firms of different sizes and ownership structures, pursuing different objectives. On the demand side, consumers differ with respect to their consumption patterns and their willingness or ability to switch suppliers. ${ }^{6}$ These dimensions of heterogeneity are key to go beyond the estimation of average pass-through rates and thus understand the sources of pass-through.

The paper proceeds as follows. Section 2 summarizes the related literature. Section 3 describes the functioning of the German electricity market. We describe the data in Section 4. Section 5 presents the econometric model, proposes a pricing equation for the German wholesale electricity market and discusses our identification strategy. The results on average and heterogeneous pass-through are presented in Section 6. Section 7 concludes.

\section{Literature}

The literature on pass-through is quite extensive. The seminal theoretical papers by Bulow and Pfleiderer (1983) and Bresnahan and Reiss (1985), further generalized by Weyl and Fabinger (2013), stress that pass-through rates depend on the extent of market powerboth upstream and downstream - and demand curvatures. The typical result is that the transmission of cost shocks to retail prices is incomplete and that it increases with the degree of competition and demand elasticity. Specifically, Weyl and Fabinger (2013) show that, under imperfect competition, pass-through is not only determined by the elasticities of supply and demand but also by the curvature of demand.

Several empirical papers confirm that markup adjustments are an important determinant of incomplete pass-through and propose possible mechanisms. Among others, the following explanations have been brought forward in the industrial organization and trade literatures: price rigidities (Devereux and Engel, 2002; Goldberg and Hellerstein, 2012; Nakamura and Zerom, 2010), long-term contracts (Bettendorf and Verboven, 2000), markup adjustments along the supply distribution chain (Bettendorf and Verboven, 2000; Goldberg and Verboven, 2001; Nakamura and Zerom, 2010; Hellerstein and Villas-Boas, 2010), as well as nonlinear pricing and vertical restraints (Bonnet, Dubois, Villas Boas, and Klapper, 2013).

\footnotetext{
${ }^{6}$ Gugler, Heim, and Liebensteiner (2016) document the existence of substantial differences in search intensity among German customers in electricity retail markets. They show that these heterogeneous search costs affect prices, finding an inverted U-shaped relationship between consumer information and price dispersion.
} 
Most of these studies use structural models to recover mark-ups and pass-through rates and model the mechanisms that explain incomplete pass-through rates. The main reason for the use of structural models is that costs are rarely observed by the researcher. There is also a literature using reduced form approaches. For instance, Deltas (2008) studies asymmetric pass-through in the US retail gasoline market and finds prices respond faster to wholesale price increases than decreases. This asymmetric response, as well as the speed of adjustment, are shown to be a consequence of retail market power. Miller, Osborne, and Sheu (2015) study the pass-through of industry-wide cost changes to downstream cement prices. In contrast to most other studies, they find that pass-through is more than complete, i.e. it exceeds $100 \%$, and that it is largely unaffected by the degree of competition.

While most of these papers focus on markets such as grocery goods, petroleum, or automotive retail, the analysis of energy markets is surprisingly scarce. Few studies look at wholesale electricity prices. For instance, Zachmann and Von Hirschhausen (2008) use time series methods and find that cost pass-through between EU emissions allowances and electricity future prices in Germany is incomplete and asymmetric: positive cost shocks are transmitted more strongly and/or quickly to the final prices than negative cost shocks. Fabra and Reguant (2014) find that emissions costs are almost fully passed through to electricity prices. Their explanation based on a structural model is that firms have weak incentives for markup adjustment due to the very limited elasticity of demand in wholesale electricity markets.

The only study we are aware of to examine pass-through to retail tariffs is Mirza and Bergland (2012), who use time series data to estimate the pass-through of wholesale price changes to variable price contracts in Norway. They estimate a partial adjustment model and find asymmetry in price transmission in the sense that positive price shocks are passed on more quickly than negative ones.

Our study is therefore the first to estimate cost pass-through to electricity retail prices using a large and disaggregated panel dataset including both price and cost data, as well as distinguishing several dimensions of heterogeneity in pass-through rates.

\section{The German electricity market}

The German market is characterized by a vertical structure comprising a generation segment, a wholesale market, and retail markets (see figure 1). The transmission network ensures that energy generated or imported is delivered to regional supply companies, which then distribute it via low or medium voltage distribution networks to energy re- 
tailers and final customers. Finally, a parallel balancing market ensures that the necessary voltage is maintained in the network at any given time.

\section{Insert Figure 1 here}

The generation segment in Germany is dominated by three vertically integrated, although legally unbundled, utilities: E.ON, RWE, and Energie Baden-Württemberg (EnBW). Moreover, a fourth strong vertically integrated player, the Swedish firm Vattenfall, entered the market in 2002. They jointly meet 2/3 - 3/4 of the total German electricity demand. The remaining German energy needs are covered through local production by a large number of municipal providers, other smaller producers, and imports from abroad. In the wholesale market, most of the electricity generated is either passed on internally to the retail outlets of the vertically integrated producers or sold to other retailers. Since 2002, the German wholesale energy market has been at least partially determined through the European Energy Exchange (EEX) market located in Leipzig.

Although the percentage of energy trade covered through the EEX has increased, ${ }^{7}$ most energy trade between wholesalers and retailers in Germany still occurs through over-thecounter (OTC) long-term bilateral contracts between producers and suppliers. According to the German competition authority - the Bundeskartellamt - in 2011 the German wholesale electricity market was characterized by joint dominance by the four aforementioned big players (Bundeskartellamt, 2011). These companies are also the main players in the retail market and still own parts of the network.

The German retail energy market is fairly concentrated as well with the big-four utilities covering almost half of national demand. In 2004, the European Commission noted (Case No COMP/M.4110 - E.ON / ENDESA pg. 10): "In the market for retail supply to small customers E.ON leads ([5-15 per cent]), followed by RWE ([5-15 per cent]), and RWE and EnBW [sic, should read: EnBW and Vattenfall] with $[<10$ per cent] and $[<10$ per cent] respectively. Other companies, including EWE and RheinEnergie, collectively represent [55-65 per cent] of this market." Although there were some dynamics in the evolution of national market shares of the main players during the 2000s, the overall picture did not change substantially. All big players lost some market share over time, yet, at the national level, they continue to cover almost half of the market.

This rather aggregated picture is partially misleading. Retail energy markets are regional in scope, at least for what concerns households and small commercial customers.

\footnotetext{
${ }^{7}$ For instance, Ockenfels, Grimm, and Zoettl (2008) report that only 15\% of energy consumption was traded at the EEX in 2008. A 2013 EEX press release mentions that the share of EEX in the German market rose to $20 \%$ (EEX, 2013) and in 2015 increased further up to 30\% (EEX, 2015).
} 
In its 2009 monitoring report, the German regulator stated: "Geographically, the relevant market for the supply of basic household costumers has to be defined at the level of the coverage area - i.e., the low voltage network necessary to supply [energy]" (Bundesnetzagentur (2009, p. 77-79)). These regional markets, defined by the coverage areas, differ substantially in terms of market structure, level of competition, and, accordingly, retail prices. In particular, the four big upstream players are also downstream incumbents in various regions. ${ }^{8}$

Several of the small vertically integrated providers (particularly the municipal providers) are also incumbents in different regional markets, generally in the municipalities where they operate. Figure 2 represents the geographical dispersion of incumbent types. While municipal utility incumbents (green) are scattered all across Germany, RWE (light blue) is mostly active in the eastern and western parts of the country. EnBW's areas of incumbency (navy) are mostly in the southwest, whereas Vattenfall's activities (orange) are focused on Berlin and Hamburg. E.ON (red) covers large regions of Germany, except in the western part. Finally, areas served by independent providers (gray) and providers with mixed ownership structure (white; typically jointly owned by a big-four firm, and/or municipalities and/or private investors) are scattered across Germany.

\section{Insert Figure 2 here}

While several retailers offer different tariffs in each of these regions, incumbent providers are legally obliged to sell energy at a baseline tariff to all household customers who do not explicitly choose another provider. Accordingly, this baseline tariff constitutes an upper bound for the energy retail prices in a given region because it is automatically chosen by customers unwilling or lacking the information to switch supplier. As a consequence, incumbent providers have particularly high market power over these customers. Thus, baseline tariffs should also be expected to be less responsive to changes in costs than those offered by the competitive fringe to more informed customers with lower switching costs.

Although German electricity retail markets were liberalized in 1998 - which resulted in substantial new entry - and each retailer has non-discriminatory access to all customers in each regional market, German household customers show a great degree of inertia.

The German regulator reports that while customers had, on average, a choice of 97 providers in each regional market in 2013, incumbent providers still served 79 percent of total households in German regional markets in 2014, 34 percent of which were still supplied at the most expensive baseline tariff (Bundesnetzagentur (2014)). The number of

\footnotetext{
${ }^{8}$ According to German law, the incumbent is the firm that serves the majority of household costumers in a local market at a given point in time. The incumbent provider is newly defined every three years.
} 
households switching providers has grown at an increasing rate over time, yet incumbent providers have maintained a very strong customer base. In 2014, 3.6 million households switched electricity providers, which accounts for less than $10 \%$ of all households in the country.

\subsection{Retail price structure}

Our empirical analysis focuses on the evolution of retail prices, in particular on their relationship with wholesale prices and network charges. Retail tariffs entail several components. On the one hand, they are affected by electricity wholesale prices that constitute the main essential input for retailers. On the other hand, they are also strongly influenced by other factors, including the (regulated) cost of transmission and distribution, concession fees, as well as taxes and other fees. In its 2012 monitoring report (Bundesnetzagentur (2012)), the German regulator discusses the structure of retail tariffs in depth for household customers, whose national average composition for the 2006-2012 period is reported in figure 3.

\section{Insert Figure 3 here}

These average values are useful to understand the various components of retail tariffs. However as discussed above, retail electricity markets are inherently regional, as demand is localized at the level of the distribution network and supply also differs regionally. Therefore, retail tariffs present a lot of cross-sectional variation across, as well as timeseries variation within regions. The German regulator reports that the cost of energy purchase varies within different types of firms. Since 2007, entrants achieved on average more favorable conditions mostly because they buy energy from the wholesale markets through shorter-term contracts and wholesale energy prices have decreased. There also appears to be substantial regional variation in electricity purchase and distribution costs varying between less than $7.5 \mathrm{ct} / \mathrm{kWh}$ mostly in the north and center-east of Germany to more than $9.5 \mathrm{ct} / \mathrm{kWh}$ in Central Germany (Bundesnetzagentur (2010)). Final retail tariffs are further influenced by network charges. On average, these decreased from 7.30 to 5.81 ct/kWh between 2006 and 2010 and then increased again during subsequent years. But also in this case there is quite substantial regional heterogeneity in the fees' levels. For example, the ratio of the $95^{\text {th }}$ and the $5^{\text {th }}$ percentile in the yearly distribution of network charges ranges from 1.62 to 1.96 over the sample period, indicating substantial dispersion. Other costs, such as the concession fee, also exhibit significant regional differences, varying by over $75 \%$ across different states. 
Finally, demand conditions are heterogeneous as well. Consumers' behavior and, especially, their willingness or ability to switch supplier differ across regions. For instance, customers living in urban areas tend to switch more because they tend to be better informed and because they face a larger set of available tariffs. Moreover, switching behavior tends to be positively correlated with income, education, and other attributes, while vulnerable customers tend to switch less often (e.g. Hviid and Waddams Price (2014), Waddams Price, Webster, and Zhu (2013), and He and Reiner (2015)). The heterogeneity in energy purchase costs, network charges and fees, consumer switching behavior, as well the different local competitive conditions described above leads to significant retail price dispersion across local markets and, within them, over time.

\section{The data}

The main data source for the analysis is the price comparison site Verivox, which provides highly disaggregated data on energy retail prices, specifically, monthly price data between January 2007 and August 2014 for 8,192 different postal codes (located in 6,205 cities across all 16 German states) from 893 different incumbent providers and 497 different non-incumbent providers. For each postal code and month, we observe prices for three types of household consumption (differentiated by yearly energy consumption: 1,500 kWh, $2,800 \mathrm{kWh}, 4,000 \mathrm{kWh}$ ) at the incumbent provider's baseline tariff and the overall least expensive offer for that particular regional market. Overall, we have 6 different prices for each postal code and month, which we convert into $€ / \mathrm{mWh}$. The data-set thus includes up to $\sim 4$ million observations. Due to some data limitations for the control variables and the inclusion of lagged values, the actual estimation sample comprises 3,941,340 observations in total and 1,970,670 observations in the tariff-specific sub-samples.

In Table 1, we present summary statistics on retail prices in the data-set. Average tariffs substantially vary both within and across consumer groups. The baseline tariff constitutes the highest price in a given market. Therefore, we can infer the lower and upper bound of the distribution of retail prices. These bounds are used to define the variable 'price dispersion' which represents the difference between the most and least expensive tariff in each postal code and period. For example, over the entire sample period, the average lowest price per $\mathrm{mWh}$ at $2,800 \mathrm{kWh}$ per year was $€ 188.1$, while the average annual baseline tariff was $€ 255.2$. Thus, $€ 67.1$ per $\mathrm{mWh}$ or more than $25 \%$ could have been saved by switching from the baseline tariff to the least expensive tariff.

\section{Insert Table 1 here}


In Table 2, we report how frequently each firm type is observed as the incumbent retailer and as the retailer with the best tariff. In most German postal codes (58\%) the incumbent provider is one of the big-four firms. Municipal providers make up 19\% of incumbents, while another 19\% have a joint ownership structure. Only 3\% of incumbents are independent firms. This picture drastically changes when we instead consider how often each firm offers the lowest tariff: $57 \%$ of least expensive tariffs are offered by independent retailers, $22 \%$ by the big-four firms - mostly through eprimo $\mathrm{GmbH}$ (owned by RWE), 'E wie einfach $\mathrm{GmbH}^{\prime}$ (owned by EON) and Vattenfall-11\% by municipal utilities, and $9 \%$ by other firms.

\section{Insert Table 2 here}

The data on the costs of purchasing and transmitting electricity are obtained from EEX and ene't respectively. The data provider ene't publishes an in-depth database containing the charges for transmitting energy through local German distribution networks. These charges are structured as a two-part tariff: in addition to a yearly base price, energy retailers also pay a variable price for the quantity of energy they transport through the network. We aggregate these network-level data to the level of postal codes and calculate the total cost per mWh of routing energy through distribution networks, depending on the consumption level. The ene't data also include information on the concession fees retailers pay to municipalities for the right to install power lines and other infrastructure. To capture energy wholesale prices we employ the Phelix current-price index provided by EEX, that is, the cost of purchasing a mWh of energy deliverable in the current month. ${ }^{9}$ We aggregate these cost factors (network charges, concession fees and wholesale energy) into a single cost variable, indicating the per-mWh cost of providing energy. Note that while network charges and concessions fees are postal code-specific, thus varying across regions and time, wholesale prices are uniform across Germany and only vary over time.

Figure 4 illustrates the evolution of per-mWh-prices for different tariffs and costs over the sample period. The incumbent baseline tariffs (figure 4, panel (a)) increase steadily over the course of seven years from a price of roughly $€ 210$ to around $€ 310$, indicating a price increase of almost $50 \%$ on average, with price adjustments happening mostly at the beginning of each year. The $5^{\text {th }}$ and $95^{\text {th }}$ percentiles remain close to and stable around the mean, suggesting that price dispersion of baseline tariffs is low and constant.

Plotting the best available energy prices over the sample period (figure 4, panel (b)), we find no signs of an increasing trend: the price per mWh mostly remains in a narrow band between $€ 180$ and $€ 200$, with a sharp drop in 2012 that is offset by an increase in 2013 .

\footnotetext{
${ }^{9}$ All our findings are robust to using month-ahead, quarter-ahead or half-year ahead wholesale prices instead.
} 
Finally, looking at the evolution of costs over time (figure 4, panel (c)) we see a significant peak in 2008, while costs mostly remain in the range of $€ 110$ to $€ 120$ per $\mathrm{mWh}$ in the years before and after.

\section{Insert Figure 4 here}

As discussed above, the heterogeneity in costs, demand, and competitive conditions at the regional level leads to significant retail price dispersion across local markets. Figure 5 shows this geographical dispersion for one specific tariff - baseline tariff for a consumption of 2,800 $\mathrm{kWh}$ - for one particular point in time - the year 2010. The different colors represent the quartiles of the price distribution.

\section{Insert Figure 5 here}

We observe significant differences in the level of the baseline tariffs across regions. Baseline tariffs are highest in the north-eastern part of Germany, where the price of consuming one mWh of electricity lies in the $(257,302]$ interval in almost all regions. In the southeastern part, this cost range is substantially lower with almost all regions belonging to the $[207,248]$ interval. The west of Germany has more homogeneous prices, with most values lying in the second and third quartile.

The baseline tariff offered by the local incumbent is always the most expensive tariff in a given market, while the least expensive alternative tariffs are typically offered by smaller competitors. In Figure 6 we report the within-network area price dispersion in 2010 calculated as the difference between the baseline tariff and the least expensive tariff available in each postal code for a consumption level of 2,800 kWh per year. The different colors represent the quartiles of the price-dispersion distribution.

\section{Insert Figure 6 here}

There is significant price dispersion in each area and significant cross-area differences in the size of this dispersion. It varies between $€ 26$ (lowest value of the first quartile) and $€ 107$ (highest value of the fourth quartile) by mWh consumed. This is quite substantial given that the average baseline tariff (best) price for consumption of one $\mathrm{mWh}$ is around $€ 260$ (€190).

\section{Insert Table 3 here}

Finally, we employ a large number of control variables at the postal code level which are also obtained from ene't. These include: the total population, the number of available distribution grids, their total length, the capacity of energy transformers, the total number 
of household connections (metering points), network losses in percent, cost of network losses in $€$, as well as total energy transmitted. Table 3 contains summary statistics on network charges, wholesale prices and the control variables.

\section{Model and estimation equation}

The empirical model we apply to the data aims at estimating the pass-through rates of network charges and wholesale prices on retail tariffs, while at the same time controlling for local supply and demand conditions. Like Miller, Osborne, and Sheu (2015), we assume that regional providers are free to set retail tariffs according to a pricing function that represents the equilibrium strategy for a given consumer demand schedule in a competitive game. Retail electricity contracts are horizontally differentiated, as each consumer can only purchase energy from the local providers operating in their area of residence. Even though electricity is a rather homogeneous good, contracts are perceived by costumer to be vertically differentiated, as the several tariffs of the different retailers in a given regional market are offered under different conditions (length of the contract, conventionally produced or 'green' electricity, bonuses, quality of service, etc.).

The price $p_{\text {ifrct }}$ of consuming one mWh of electricity under tariff $i$ (incumbent base, overall best), for firm $f$ (municipal provider, big-four provider, independent provider, other provider) in region $r$ (postal code), at consumption level $c$ (1500, 2800 or $4000 \mathrm{kWh} /$ year) in month $t$ (January 2007 until August 2014) is therefore given by:

$$
p_{i f r c t}=\alpha+\beta \operatorname{cost}_{r c t}+\delta X_{r t}+\eta_{i}+\phi_{f}+\rho_{r}+\zeta_{c}+\tau_{t}+\varepsilon_{\text {irct }}
$$

where cost $_{r c t}$ is the aggregate cost (network charges, concession charges and wholesale energy price) per mWh in region $r$ for consumption bundle $c$ in month $t{ }^{10}$ The coefficient of the cost variable, $\beta$, measures the degree to which changes in costs are passed on to retail prices.

The matrix of controls $X_{r t}$ accounts for time-varying differences across regions in demand and supply conditions. Specifically, we control for the total population, the total number of household connections, the number of available distribution grids, their total length, the capacity of energy transformers, network losses in percent, cost of network losses in $€$, as well as total energy transmitted. ${ }^{11}$ We also add a large set of fixed-effects.

\footnotetext{
${ }^{10}$ Network charges entail two components: a yearly fee per user independent of consumption and a variable fee that is function of the consumed electricity. Therefore even though we calculate the network charge per $\mathrm{mWh}$, it differs across consumption bundles.

${ }^{11}$ Several of these variables are expected to control for the cost to run the transmission and distribution network. Germany adopted an incentive-based regulation in 2009 under which providers are incentivized
} 
First, we have fixed-effects for the different tariffs' types $\eta_{i}$. Second, we control for firm types $\phi_{f}$ - municipal providers, big-four providers, independent providers, and others. Third, we allow for region-specific time-invariant unobserved heterogeneity through a set of 8,192 postal code dummies, $\rho_{r}$. Fourth, we have three consumption basket dummies, $\zeta_{c}$. Finally, we include a full set of 92 month-specific fixed-effects, $\tau_{t}$. The error term, $\varepsilon_{i r c t}$, is a residual that summarizes unobservable factors. It is assumed to be heteroscedastic and it is allowed to cluster at the level of individual electricity providers. ${ }^{12}$

We estimate equation 1 in four different specifications in order to allow for heterogeneity in the pass-through coefficient of aggregate costs $\beta$. In a first step, we assume that $\beta$ is common to all observations, thus reflecting the average pass-through of costs to retail prices in the whole sample. Second, we allow the pass-through to differ for the different tariffs $\beta_{i}$ as we expect the tariff types to target different costumer groups in terms of willingness or ability to switch. Therefore, we run separate regressions for different tariff types $i$. Third, we estimate firm-type $f$ specific pass-through rates so that we obtain separate pass-through rates for municipal, big-four, independent and other retailers as well as the different tariff types $\beta_{i f}$. Finally, we investigate the evolution of the pass-through rate over time by estimating tariff, firm, year-specific pass-through coefficients, $\beta_{i f t}$.

\section{Results}

In this section, we discuss the main regression results. Table 4 reports different specifications that focus on the average pass-through. In the first column, we look at the most aggregate specification where the tariffs are pooled. We estimate an incomplete average pass-through rate of $59 \%$ : a $€ 1$ reduction in the cost of providing electricity to retail customers - for instance due to a change in the cost of energy or the cost of transmission and distribution - is transformed in a $59 €$-cent decrease in costumers' prices, on average. The specification seems to work very well, as we are able to explain over $80 \%$ of the variation in tariffs. The control variables have intuitive and significant effects on prices. Tariffs are positively related with demand drivers such as population and the number of connections as well as with costs drivers such as network loss and their costs. Retail prices decrease

to cut costs. Network charges are, therefore, directly related to costs. Hence, the control variables mimic the same factors used by the German regulator to determine the network charges.

${ }^{12}$ This level of clustering aims at capturing that many providers - especially the big four - mostly offer tariffs that are homogenous across regions. However, as we discuss above, there are many other providers that are only active in specific regions. Therefore as a robustness check, we clustered the standard errors also at the regional level (postal codes or state-level) to account for these different correlation patterns. Results remain unaffected. 
with measures of efficiency such as the number of grids, the total grid lengths, and the transformer capacity.

\section{Insert Table 4 here}

We then split the sample according to the two tariff types - 'incumbent base' and 'overall best'- which allows us to estimate heterogeneous pass-through rates depending on the customers' types. As discussed above, these tariffs should reflect different segments of the market. We expect customer who buy the 'best' tariff to be better informed and to have smaller switching costs. Therefore, we expect these tariffs to be more competitive and to reflect more strongly changes in costs. The coefficient estimate of the cost variable increases to $70 \%$ for the overall best tariff, while it drops to $49 \%$ for the baseline tariff. This means that the pass-through rate for the most competitive tariffs is significantly higher than for the less competitive one. Interestingly, while our specification captures the variation of baseline tariffs very well ( $\mathrm{R}^{2}$ of $96 \%$ ), it explains the variation of overall best tariffs to a lesser degree $\left(\mathrm{R}^{2}\right.$ of $\left.67 \%\right)$.

In the next step we allow the pass-through to vary across firm types in an effort to analyze whether firms differ with respect to downstream market power. We would expect independent providers to have a higher pass-through rate than the 'big four' utilities and, potentially, the municipal providers, because the latter are vertically integrated firms with an established brand name, which could grant them market power. Table 5 reports the results.

\section{Insert Table 5 here}

The rate of cost pass-through to the incumbent base tariff is close to and not significantly different from $49 \%$ for all firm types, which is the same pass-through rate we found in the pooled specification (table 4, column 2). In the more competitive market segment, we find that independent firms exhibit the highest degree of pass-through. While the big four, municipal and other firms have average pass-through of $61 \%$ and $58 \%$ and $53 \%$ respectively, the pass-through rate for the small independent retailers is $74 \%$. The difference in the pass-through rate of independent firms types is statistically significant higher than that of 'other' firms ( $p=0.001)$, municipalities ( $p=0.02)$, and the big four firms ( $p=0.06$ ).

Thus, while we find some evidence for supply side heterogeneity, its extent appears to be limited: the pass-through rate to baseline tariffs is almost identical across firms, the pass-through rate to competitive tariffs is $15-20 \%$ higher for independent suppliers. Therefore, the extent of pass-through seems to be mostly driven by demand side factors - i.e., by the inability to switch supplier - rather than the structural characteristics of the 
providers. This is in line with Weyl and Fabinger (2013) who find that under imperfect competition the curvature of demand plays a central role to determine the pass-through rate when firms have market power.

The next dimension of heterogeneity that we exploit in the econometric analysis is time. In table 6 we report the results for the specifications where we estimate a time-dependent pass-through for the different tariffs. For the 'incumbent base' tariff the pass-through remains more or less constant around $50 \%$ over time. In contrast, the best tariff passthrough rate, starts out at around $40 \%$ at the beginning of the sample period, increases in 2010 and, after a dip in 2011, becomes almost unity for the final years in the sample. The difference between the pass-through rates is significant for the years 2012 to 2014.

\section{Insert Table 6 here}

This result appears particularly interesting as it suggests that, after 2011, the passthrough rate for the most competitive part of the market, i.e., the best tariffs, is almost complete. This is consistent with almost perfect competitive outcomes in this segment of the market.

The final step of our empirical analysis is to allow the maximum amount of heterogeneity in the pass-through rates, which are estimated to be tariff, firm, and time-specific. Because of the large amount of estimated coefficients, we present the results graphically in figures 7 and 8 for the baseline and best tariffs respectively.

\section{Insert Figure 7 here}

\section{Insert Figure 8 here}

While we see a different evolution of pass-through rates across tariffs, i.e., market segments, as before, we do not find significant differences across firms. Thus, all types of firms in our data exhibit remarkably similar dynamics in their pass-through behavior over time.

However, for most time periods, we see that the pass-through rates of independent firms tend to be the highest, but not by a large margin. Again, these results seem to suggest that the pass-through rate is mostly driven by consumer behavior as represented by the different tariff types rather than by firms' characteristics.

\section{Conclusion}

In this paper we study the pass-through of cost shocks to household retail electricity tariffs in Germany. We assemble a very rich database containing almost 4 million observations 
and covering different retail tariffs for three types of household consumption (differentiated by yearly energy consumption: 1,500 kWh, 2,800 kWh, 4,000 kWh) for more than 1,300 firms operating in 8,192 different postal codes between January 2007 and August 2014. We have precise information on the two major cost drivers for electricity retail prices - the regulated network fee and the wholesale electricity prices - which together constitute more than $2 / 3$ of the cost of providing electricity to household customers and are able to control for most other cost factors through several time-varying drivers and numerous fixed effects.

We find that pass-through is incomplete and, on average, amounts to around $60 \%$. Yet, we observe several dimensions of heterogeneity that are consistent with theoretical predictions. Pass-through rates respond to different demand elasticities and competition levels. They are significantly larger for those segments of the markets where demand is more elastic because consumers have lower switching costs and consider products to be less differentiated, while they are higher in market segments where the opposite is true. The average pass-through of $60 \%$ decreases to around $50 \%$ for the incumbents' baseline tariffs and increases to $70 \%$ for tariffs designed for the more mobile costumers. Moreover, passthrough rates tend to be larger for independent retailers if compared to typical incumbent retailers such as the municipal providers and the big four firms (E.ON, RWE, EnBW, and Vattenfall). The latter are expected to have more market power because they are larger, vertically integrated, and have more established brand names that might serve as a lock-in device for less mobile costumers. However, the differences in pass-through rates across firm types appear to be limited and are statistically significant only in the competitive market segment.

We also observe quite different time dynamics for the different tariff types. While the pass-through to baseline tariffs remains relatively stable over time, the pass-through rate to the best available tariff increases to unity over the same time period. Since $24 \%$ of German households have switched to the competitive market segment (Bundesnetzagentur, 2015), this increase in competition is likely to entail positive and significant welfare effects. The differences across different firm types appear to be limited: while the changes over time are substantial, the pass-through rates of different firm types tend to move in tandem and are not significantly different from each other. Therefore, it appears that the extent of local cost pass-through and, in turn, local market power is predominantly driven by demand side factors, i.e. the ability of consumers to switch electricity provider. 


\section{References}

BetTendorf, L., AND F. Verboven (2000): “Incomplete transmission of coffee bean prices: evidence from the Netherlands," European Review of Agricultural Economics, 27(1), 1-16.

Bonnet, C., P. Dubois, S. B. Villas Boas, and D. Klapper (2013): “Empirical evidence on the role of nonlinear wholesale pricing and vertical restraints on cost pass-through," Review of Economics and Statistics, 95(2), 500-515.

Bresnahan, T. F., and P. C. ReIss (1985): “Dealer and manufacturer margins," The RAND Journal of Economics, pp. 253-268.

Bulow, J. I., And P. Pfleiderer (1983): "A note on the effect of cost changes on prices," Journal of political Economy, 91(1), 182-185.

BundesKartellamt (2011): "Sektoruntersuchung Stromerzeugung Stromgroßhandel. Bericht gemäß 32 GWB," Bonn.

Bundesnetzagentur (2009): “Monitoring report 2009," Bonn.

_ (2010): “Monitoring report 2010," Bonn.

— (2012): “Monitoring report 2012," Bonn.

_ (2014): "Monitoring report 2014," Bonn.

_ (2015): “Monitoring report 2015," Bonn.

Deltas, G. (2008): "Retail gasoline price dynamics and local market power*," The Journal of Industrial Economics, 56(3), 613-628.

Devereux, M. B., ANd C. Engel (2002): “Exchange rate pass-through, exchange rate volatility, and exchange rate disconnect," Journal of Monetary economics, 49(5), 913-940.

EEX (2013): “EEX-Märkte mit starkem Wachstum im Jahr 2013,” .

(2015): “EEX-Gruppe mit starkem Volumenwachstum im ersten Halbjahr 2015,” .

Fabra, N., And M. Reguant (2014): "Pass-Through of Emissions Costs in Electricity Markets," American Economic Review, 104(9), 2872-99.

Goldberg, P. K., and R. Hellerstein (2012): “A structural approach to identifying the sources of local currency price stability," The Review of Economic Studies, p. rds015.

Goldberg, P. K., and F. Verboven (2001): “The evolution of price dispersion in the European car market," The Review of Economic Studies, 68(4), 811-848. 
Gugler, K., S. Heim, and M. Liebensteiner (2016): “Non-Sequential Search, Competition and Price Dispersion in Retail Electricity," WU Department of Economics Working Paper, 225.

He, X., and D. Reiner (2015): “Why Do More British Consumers Not Switch Energy Suppliers? The Role of Individual Attitudes," Cambridge Working Paper in Economics, (1525).

Hellerstein, R., and S. B. Villas-Boas (2010): “Outsourcing and pass-through," Journal of International Economics, 81(2), 170-183.

Hvird, M., and C. Waddams Price (2014): “Well-Functioning Markets in Retail Energy,” European Competition Journal, 10(1), 167-179.

Joskow, P. L., ET AL. (2008): “Lessons learned from electricity market liberalization," The Energy Journal, 29(2), 9-42.

Miller, N. H., M. Osborne, and G. Sheu (2015): “Pass-Through in a Concentrated Industry: Empirical Evidence and Regulatory Implications," mimeo.

Mirza, F. M., ANd O. Bergland (2012): "Pass-through of wholesale price to the end user retail price in the Norwegian electricity market," Energy Economics, 34(6), 2003-2012.

NaKamura, E., and D. Zerom (2010): “Accounting for incomplete pass-through," The Review of Economic Studies, 77(3), 1192-1230.

Ockenfels, A., V. Grimm, And G. Zoettr (2008): “Strommarktdesign-Preisbildungsmechanismus im Auktionsverfahren für Stromstundenkontrakte an der EEX," Gutachten im Auftrag der European Energy Exchange AG zur Vorlage an die Sächsische Börsenaufsicht, 11.

Su, X. (2015): "Have customers benefited from electricity retail competition?," Journal of Regulatory Economics, 47(2), 146-182.

WAddAms Price, C. (2005): “The effect of liberalizing UK retail energy markets on consumers," Oxford Review of Economic Policy, 21(1), 128-144.

Waddams Price, C., C. Webster, and M. Zhu (2013): “Searching and Switching: Empirical estimates of consumer behaviour in regulated markets," Centre for Competition Policy, Working Paper.

Weyl, E. G., and M. Fabinger (2013): "Pass-through as an economic tool: Principles of incidence under imperfect competition," Journal of Political Economy, 121(3), 528-583. 
ZachmanN, G., and C. Von HirschHausen (2008): “First evidence of asymmetric cost pass-through of EU emissions allowances: Examining wholesale electricity prices in Germany," Economics Letters, 99(3), 465-469. 
Figure 1: The Structure of the German Electricity Market

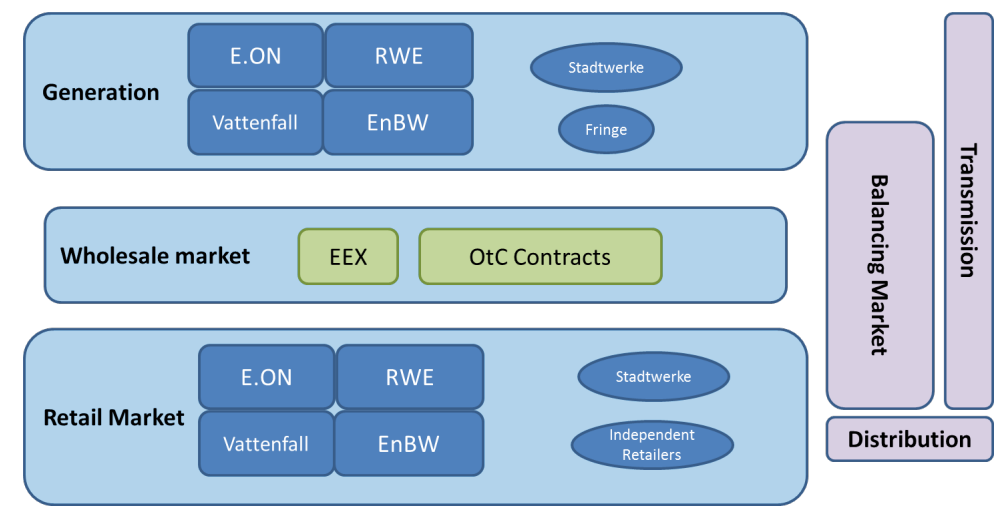

\section{Tables and Figures}

Table 1: Prices and price dispersion by consumption, 2007 to 2013

\begin{tabular}{lccccccc}
\hline \hline & 1500 & & 2800 & \multicolumn{3}{c}{4000} \\
\hline Incumbent base tariff & 289.2 & $(36.48)$ & 261.6 & $(34.98)$ & 251.9 & $(34.63)$ \\
Overall best tariff & 202.0 & $(19.19)$ & 189.2 & $(13.42)$ & 187.0 & $(13.10)$ \\
Price dispersion & 87.19 & $(34.98)$ & 72.37 & $(36.51)$ & 64.95 & $(34.62)$ \\
\hline \hline
\end{tabular}

Notes: All values in $€$ per $\mathrm{mWh}$. Standard deviations in parentheses.

Table 2: Incumbent and best price frequencies

\begin{tabular}{lcc}
\hline \hline & Incumbent tariff & Best tariff \\
Stadtwerke & .194 & .111 \\
Big4 & .581 & .224 \\
Independent & .031 & .572 \\
Others & .195 & .093 \\
\hline \hline
\end{tabular}


Figure 2: Incumbents in regional retail markets in Germany in 2010

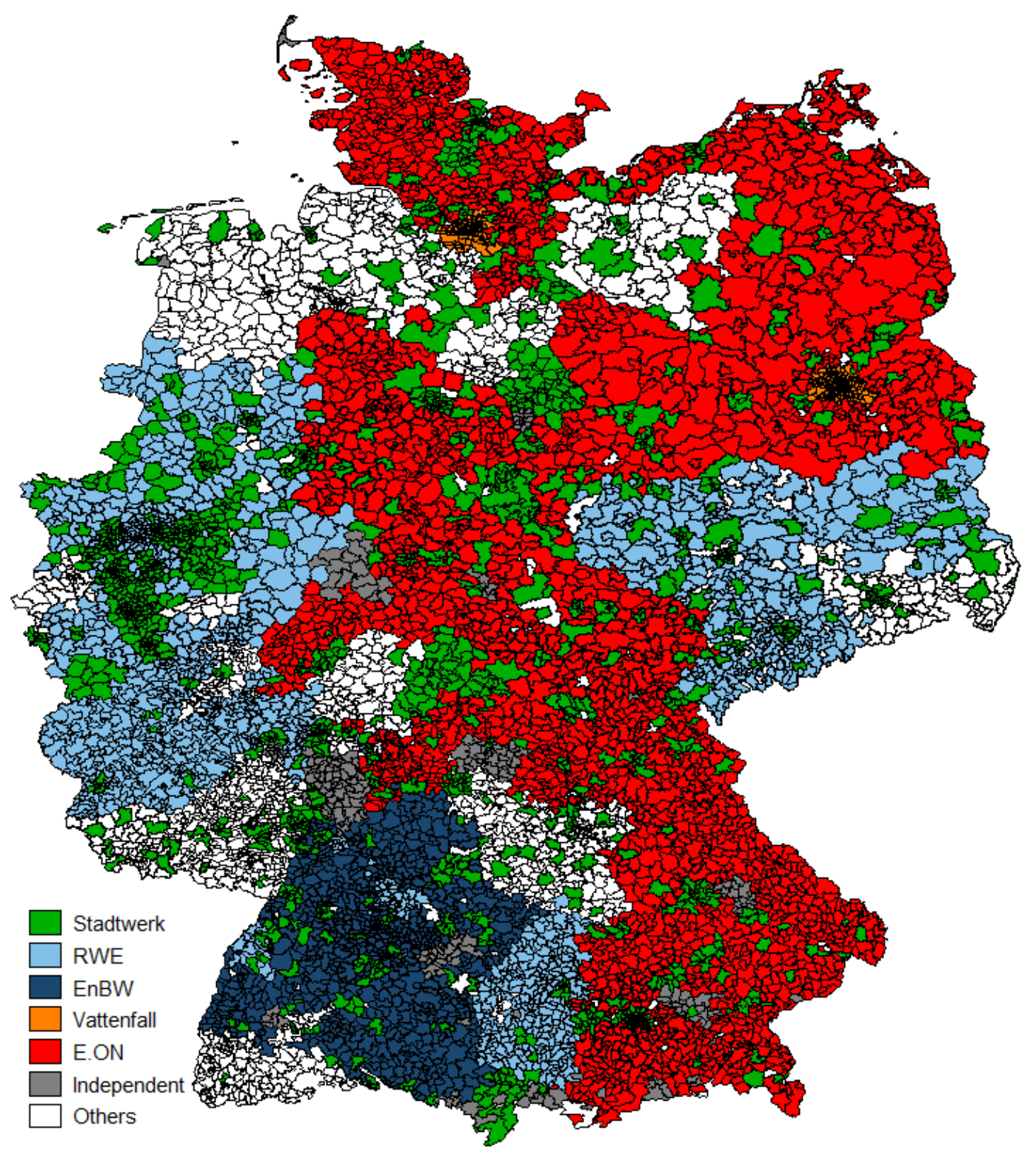

Source: Own calculations based on Verivox data. 
Figure 3: Development of Energy Purchase Prices - Weighted Averages over all Tariff Types

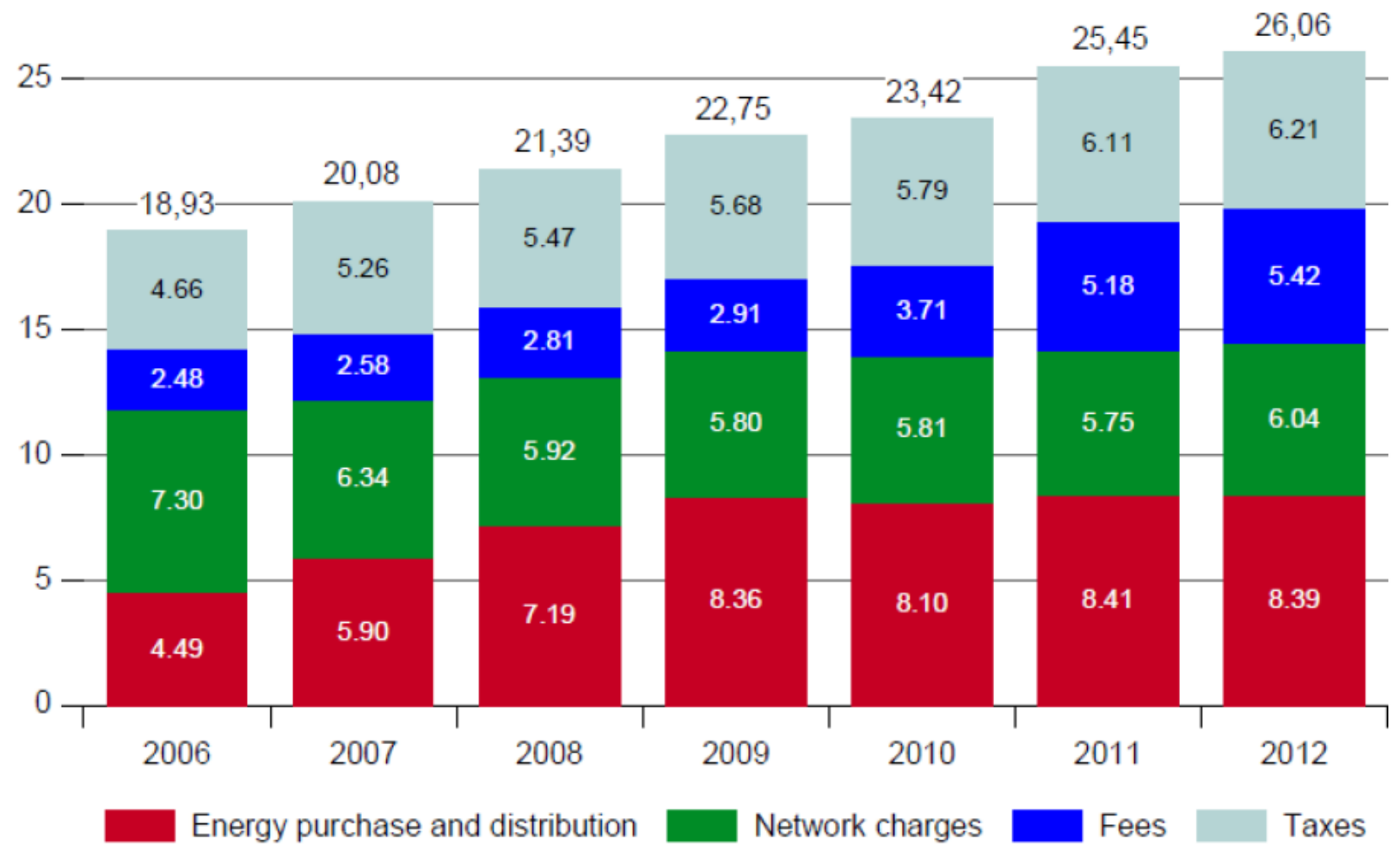

Source: Bundesnetzagentur (2012).

Table 3: Cost and control variable summary statistics

\begin{tabular}{lcccc}
\hline \hline \multicolumn{1}{c}{ Mean } & SD & Min & Max & \\
\hline Network charge $€ / \mathrm{mWh}$ & 56.72 & 10.63 & 0.00 & 104.65 \\
Concession fee $€ / \mathrm{mWh}$ & 14.87 & 3.46 & 0.00 & 23.90 \\
Phelix current-month $€ / \mathrm{mWh}$ & 44.57 & 12.19 & 26.82 & 87.94 \\
Population & 13.78 & 2.25 & 0.00 & 15.85 \\
Number of grids & 14.84 & 6.43 & 6.00 & 72.00 \\
Total grid length & 8.21 & 3.33 & 0.00 & 11.57 \\
Transformer capacity & 6.72 & 2.76 & 0.00 & 12.67 \\
Number of connections & 11.64 & 4.21 & 0.00 & 15.37 \\
Total energy transmitted & 12.65 & 4.89 & 0.00 & 19.94 \\
Network loss in $\%$ & 2.21 & 1.78 & 0.00 & 65.95 \\
Cost of network loss $€ / \mathrm{mWh}$ & 4.90 & 2.68 & 0.00 & 11.91 \\
\hline \hline
\end{tabular}

Notes: Population, grid length, capacity, connections and total energy transmitted are in logs. 
Table 4: Average pass-through of pooled costs

\begin{tabular}{lccc} 
& All prices pooled & Incumbent base & Overall best \\
\hline \hline Cost & $0.588^{* * *}$ & $0.491^{* * *}$ & $0.696^{* * *}$ \\
Population & $(0.003)$ & $(0.090)$ & $(0.058)$ \\
& $0.169^{* * *}$ & $0.216^{*}$ & $0.118^{* *}$ \\
Number of grids & $(0.011)$ & $(0.125)$ & $(0.056)$ \\
& $-0.049^{* * *}$ & $-0.098^{*}$ & 0.001 \\
Total grid length & $(0.008)$ & $(0.058)$ & $(0.023)$ \\
& $-0.155^{* * *}$ & -0.125 & $-0.180^{* *}$ \\
Transformer capacity & $(0.017)$ & $(0.312)$ & $(0.084)$ \\
& $-0.522^{* * *}$ & $-0.928^{* * *}$ & -0.117 \\
Number of connections & $(0.024)$ & $(0.336)$ & $(0.114)$ \\
& $0.216^{* * *}$ & $0.517^{* * *}$ & -0.079 \\
Network loss in \% & $(0.008)$ & $(0.147)$ & $(0.106)$ \\
& $0.516^{* * *}$ & $0.610^{* * *}$ & $0.429^{* * *}$ \\
Cost of network loss & $(0.009)$ & $(0.158)$ & $(0.080)$ \\
Total energy transmitted & $0.132^{* * *}$ & 0.131 & 0.137 \\
\hline Observations & $(0.008)$ & $(0.176)$ & $(0.114)$ \\
$R^{2}$ & $-0.027^{* * *}$ & -0.004 & -0.047 \\
\hline
\end{tabular}

Notes: Standard errors in parentheses, ${ }^{*} \mathrm{p}<0.1,{ }^{* *} \mathrm{p}<0.05,{ }^{* * *} \mathrm{p}<0.01$. 
Figure 4: Monthly average prices and costs per mWh

(a)

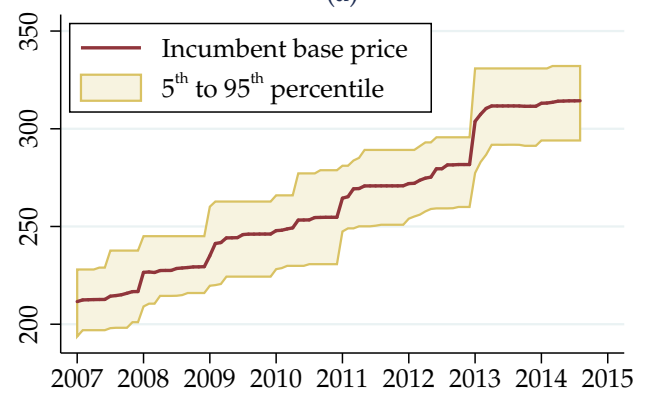

(c)

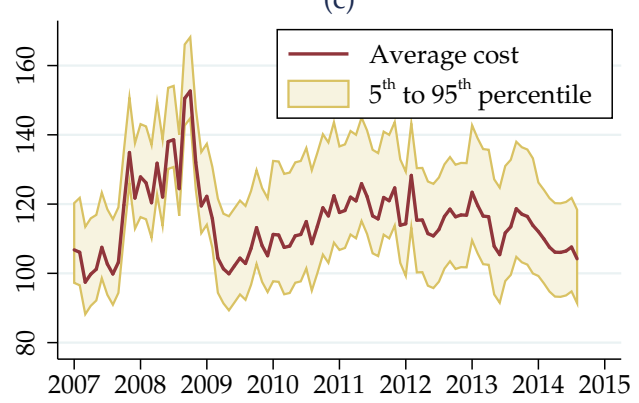

(b)

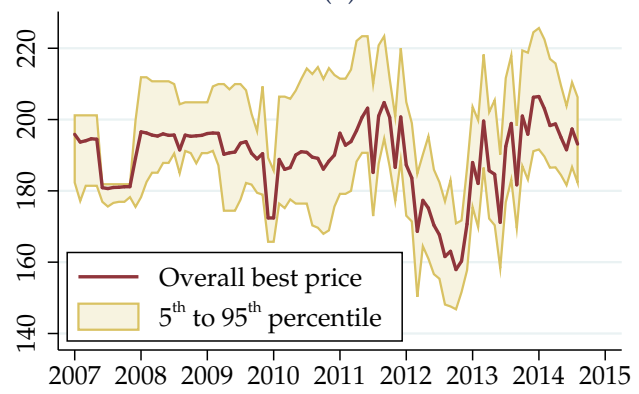

Based on a yearly consumption of $2.8 \mathrm{mWh}$. Source: Calculations based on Verivox data.

Table 5: Average pass-through of pooled costs by retailer

\begin{tabular}{lcccc}
\multicolumn{3}{c}{ Incumbent base } & Overall Best \\
\hline \hline Municipality * Cost & $0.468^{* * *}$ & $(0.082)$ & $0.575^{* * *}$ & $(0.066)$ \\
Big-four * Cost & $0.486^{* * *}$ & $(0.100)$ & $0.606^{* * *}$ & $(0.066)$ \\
Independent * Cost & $0.549^{* * *}$ & $(0.088)$ & $0.738^{* * *}$ & $(0.057)$ \\
Other * Cost & $0.512^{* * *}$ & $(0.094)$ & $0.530^{* * *}$ & $(0.059)$ \\
Population & $0.225^{*}$ & $(0.125)$ & 0.098 & $(0.061)$ \\
Number of grids & $-0.098^{*}$ & $(0.057)$ & -0.002 & $(0.024)$ \\
Total grid length & -0.138 & $(0.307)$ & $-0.151^{*}$ & $(0.085)$ \\
Transformer capacity & $-0.923^{* * *}$ & $(0.342)$ & -0.090 & $(0.112)$ \\
Number of connections & $0.515^{* * *}$ & $(0.149)$ & -0.088 & $(0.107)$ \\
Network loss in \% & $0.623^{* * *}$ & $(0.159)$ & $0.388^{* * *}$ & $(0.080)$ \\
Cost of network loss & 0.129 & $(0.176)$ & 0.143 & $(0.112)$ \\
Total energy transmitted & -0.005 & $(0.102)$ & -0.039 & $(0.062)$ \\
\hline Observations & 1970670 & & 1970670 & \\
$R^{2}$ & .96 & & .68 & \\
\hline \hline
\end{tabular}

Notes: Standard errors in parentheses, ${ }^{*} \mathrm{p}<0.1,{ }^{* *} \mathrm{p}<0.05,{ }^{* * *} \mathrm{p}<0.01$. 
Figure 5: Heterogeneity in Baseline Tariffs (2010)

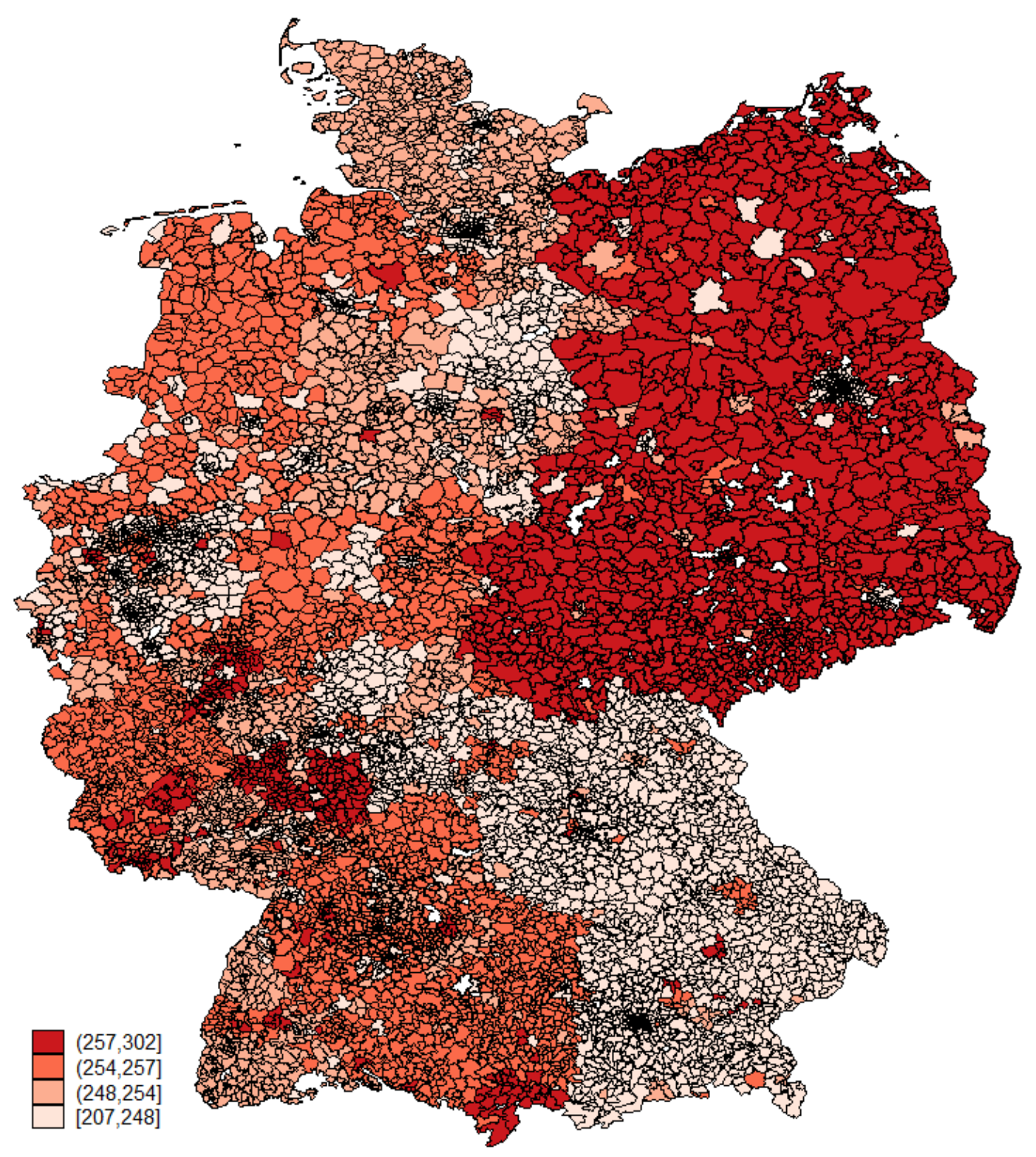

Baseline tariff in $€$ per $\mathrm{mWh}$ at $2,800 \mathrm{kWh}$ yearly consumption.

Source: Own calculations based on Verivox data. 
Figure 6: Within-Network Price Dispersion (2010)

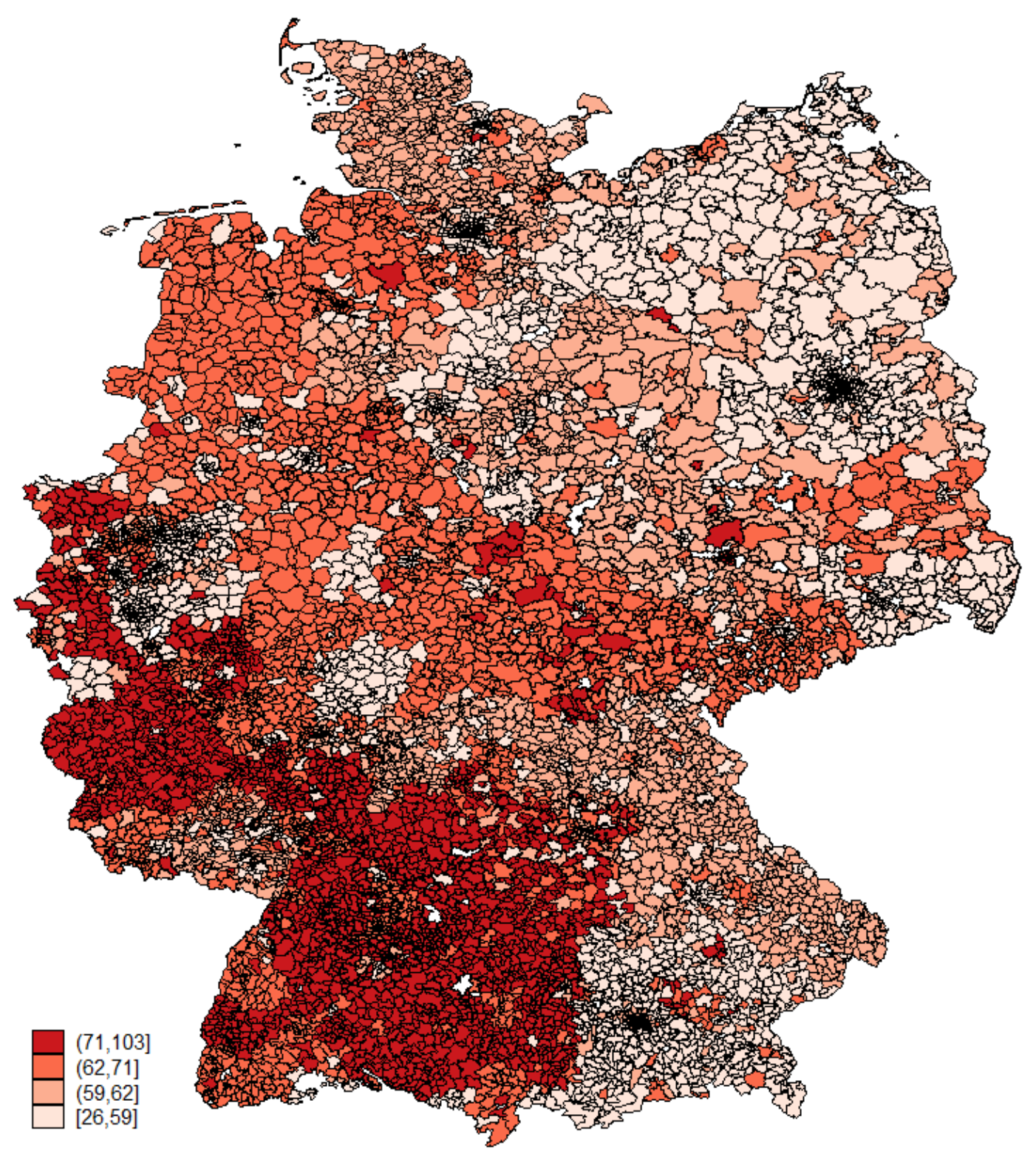

Dispersion in $€$ per $\mathrm{mWh}$ at $2,800 \mathrm{kWh}$ yearly consumption.

Source: Own calculations based on Verivox data. 
Table 6: Average pass-through of pooled costs by year

\begin{tabular}{|c|c|c|c|c|}
\hline & Incumbent base & & Dverall Bes & \\
\hline Cost * 2007 & $0.422^{* * *}$ & $(0.153)$ & $0.407^{* * *}$ & $(0.104)$ \\
\hline Cost * 2008 & $0.526^{* * *}$ & $(0.110)$ & $0.391^{* * *}$ & $(0.082)$ \\
\hline Cost * 2009 & $0.482^{* * *}$ & $(0.119)$ & $0.318^{* * *}$ & $(0.085)$ \\
\hline Cost * 2010 & $0.548^{* * *}$ & $(0.080)$ & $0.580^{* * *}$ & $(0.114)$ \\
\hline Cost * 2011 & $0.422^{* * *}$ & $(0.099)$ & $0.414^{* * *}$ & $(0.091)$ \\
\hline Cost $* 2012$ & $0.514^{* * *}$ & $(0.109)$ & $0.923^{* * *}$ & $(0.063)$ \\
\hline Cost * 2013 & $0.527^{* * *}$ & $(0.094)$ & $0.852^{* * *}$ & $(0.037)$ \\
\hline Cost $* 2014$ & $0.423^{* * *}$ & $(0.134)$ & $0.905^{* * *}$ & $(0.047)$ \\
\hline Population & 0.199 & $(0.121)$ & 0.029 & $(0.057)$ \\
\hline Number of grids & $-0.100^{*}$ & $(0.057)$ & -0.021 & $(0.027)$ \\
\hline Total grid length & -0.110 & $(0.306)$ & -0.098 & $(0.081)$ \\
\hline Transformer capacity & $-0.943^{* * *}$ & $(0.336)$ & -0.004 & $(0.111)$ \\
\hline Number of connections & $0.528^{* * *}$ & $(0.152)$ & -0.054 & $(0.086)$ \\
\hline Network loss in \% & $0.582^{* * *}$ & $(0.150)$ & $0.222^{* * *}$ & $(0.080)$ \\
\hline Cost of network loss & 0.138 & $(0.159)$ & $0.185^{*}$ & $(0.103)$ \\
\hline Total energy transmitted & -0.004 & $(0.099)$ & -0.048 & $(0.061)$ \\
\hline Observations & 1970670 & & 1970670 & \\
\hline$R^{2}$ & .96 & & .69 & \\
\hline
\end{tabular}

Notes: Standard errors in parentheses, ${ }^{*} \mathrm{p}<0.1,{ }^{* *} \mathrm{p}<0.05,{ }^{* * *} \mathrm{p}<0.01$. 
Figure 7: Yearly cost pass-through by firm-type: incumbent baseline tariffs

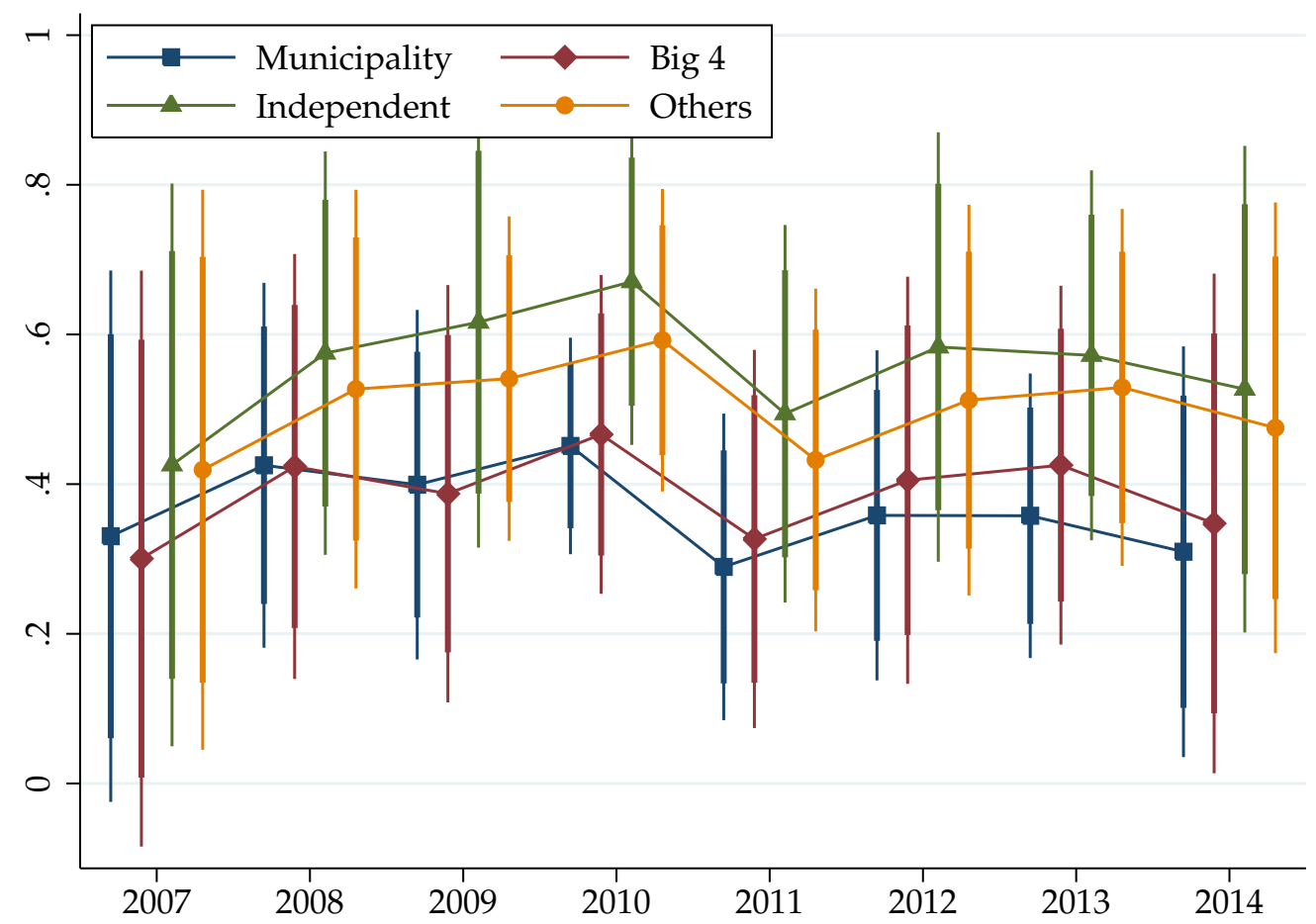

Notes: The vertical bars indicate the $95 \%$ and $99 \%$ confidence intervals of the coefficient estimates.

Figure 8: Yearly cost pass-through by firm-type: best tariffs

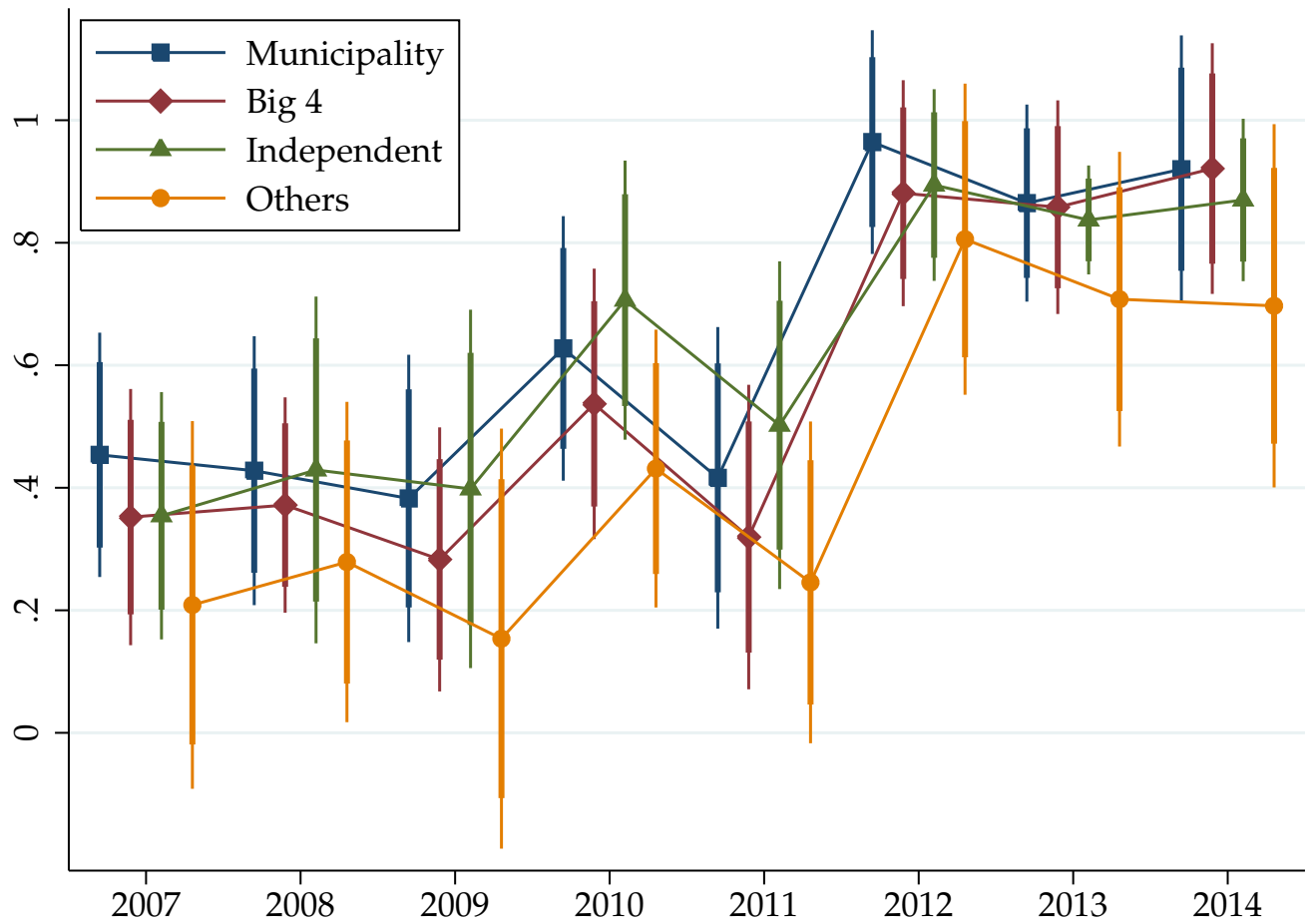

Notes: The vertical bars indicate the $95 \%$ and $99 \%$ confidence intervals of the coefficient estimates. 